\title{
DIGITAL ECONOMY AND SOCIETY: BALTIC STATES IN THE EU CONTEXT
}

\author{
Jevgenija Česnauskė \\ Kauno Kolegija, Kaunas, Lithuania, jevgenija.cesnauske@go.kauko.lt
}

\begin{abstract}
Research purpose. The high penetration of the Internet and increased level of use of digital devices create conditions for the development of the digital economy and society. Understanding and management of this model are essential whilst seeking to compete in the global market and to ensure a high standard of living for citizens. However, despite the opportunities presented by the digital economy, the Baltic States have not yet fully exploited the potential of digital technologies for sustainable development. The purpose of this research is to assess the progress of the Baltic States towards developing a digital economy and society and to identify areas requiring priority investments and action.
\end{abstract}

Design/Methodology/Approach. The Digital Economy and Society Index (DESI) published by the European Commission is used to explore the potential of the digital economy. It is an index measuring progress in digital performance through five components: connectivity, human capital, use of internet, integration of digital technology and digital public services. DESI is a crucial tool to reflect the performance of the Baltic States in the context of other European countries.

Findings. The survey shows the individual performance of each Baltic country and compares them amongst themselves as well as with other EU countries. Estonia has the highest DESI when compared with other Baltic countries; however, lower scores in connectivity and integration of digital technology components are observed. Lithuania scores high in the integration of digital technology, whereas the human capital component remains lower. Latvia is a leader amongst connectivity but descents to other Baltic countries in human capital and integration of digital technology components.

Originality/Value/Practical implications. The digital economy remains a widely discussed topic; however, a lack of unanimous scientific definition and detailed research on this economic model complicates understanding of digital technologies. It is essential for each government to analyse the model and focus on the improvement of the digital economy in order to ensure that the country remains digitally competitive in the world.

Keywords: Digital economy; Digital society; Information technology; DESI; Baltic States.

JEL codes: O33; O35.

\section{Introduction}

The beginning of the 21 st century can be distinguished by the development of advanced digital technologies, the revolution in the information space and the acceleration of economic globalisation processes. Nowadays, the development of information technology plays a major role in society and the economy. A person and society always strive to meet the growing needs in one or another field of activities, whilst the information technology expands the range of opportunities of all individuals, organisations and states.

The information technology has not only changed the models of business and consumer behaviour in the modern economy but also laid the foundation for various processes: high technology-based production and economic activities, development of financial services, changes in education concepts and standards and the digitisation of entertainment and leisure areas. This infrastructure, formed based on the electronic interoperability, is becoming the new direction of the development of global technology, in which the economic activities are based on digital technologies.

(C) 2019 Authors. This is an open-access article licensed under the Creative Commons Attribution-NonCommercial-NoDerivs License (http://creativecommons.org/licenses/by-nc-nd/3.0/) 
The digital economy promotes competition not only within the country but also on a global scale. Therefore, any country seeking to compete in the global market should properly use the potential of the digital economy and promote digital progress. Foreign investors who see the Baltic States as one region are very interested in the progress of all three countries. Thus, it is essential for the Baltic States to properly position their advantages in the global market as well as to identify the areas that need to be improved.

This article aims to perform an analysis of the digital economy progress of the three Baltic States, Estonia, Latvia and Lithuania, in the context of the whole European Union. In order to reach this aim, the following objectives have been set out: to represent the essence of digital economy by highlighting the advantages and risks as well as to assess the digital economy progress level of the three Baltic States in the context of the whole European Union by distinguishing the areas of these countries that need to be improved. The progress of digital economy and society of Baltic States is compared with the average of the European Union in order to assess if the following hypothesis is confirmed: The Baltic States do not fully exploit their potential of digital technologies for the development of economy.

\section{Literature Review}

The new society of the 21 st century can be viewed as continuously evolving information society, whereas the new economy of the 21 st century is the digital global world economy that operates in the medium of the information technology (Morkunienè, 2002). Starting from the 1970s, the ending of the 20th century can be distinguished by a rapid transformation of the whole world because of the penetration of information technologies into everyday life. This transformational process is multidimensional and has unevenly affected various countries. However, it can be stated that, in our days, technology does not determine society: it is a society (Cardoso \& Castells, 2006).

The developing digital economy and society are completely different for the traditional models. This new model is not a temporary trend and can impact the competitiveness of a country on a global scale (Parente et al., 2017). Thus, the digitisation of the economy is the topicality of these days that impacts almost all areas: those of a human as an individual and of the society.

The concept of digitisation can be used in both the narrow sense and the broad sense. In the narrow sense, digitisation means the transformation of information into a digital form that is convenient in both management and usage. In the broad sense, digitisation is the driving force of the modern life, a modern global tendency of the development of the economy and society that increases the effectiveness of the economy as well as the quality of life (Khalin \& Chernova, 2018).

Although, in the scientific literature, the term of digital economy is commonly identified as the web economy, new economy, e-economy and information economy, the term of the digital economy is much broader, covering not only operations in the cyberspace, but it also encompasses the increasing use of information technology in all sectors of the economy and everyday life. Thus, the digital economy can be described as an ability to create added value by taking advantage of the possibilities created by information technology (Bruneckienè, 2014). Namely, the information technology is becoming the most important factor that determines the place of the country in the world and attracts the capital from countries in which there are no such opportunities or the amount of them is not sufficient (Ivanov \& Malineckij, 2017).

It is believed that the term 'digital economy' dates to 1994. In this year, a book 'The Digital Economy' describing the virtual economic system, written by a famous Canadian economist and business consultant Don Tapscott, was published (Tapscott, 1996). Afterwards, in 1995, this term was used by scientist Nicholas Negroponte, who described the ideology of digital economy as a 'conversion of its atoms to bits'. In addition, he predicted the modern formation of the digital economy and the interconnection of information, interactive and entertainment worlds into a digital network (Negroponte, 1995).

The research on the digital economy model is continued by scientists such as E. Brynjolfsson, B. Kahin, B. Johansson, Ch. Karlsson and R. Stough. During this period, the model of the digital economy, in which all 
sectors are transformed because of the impact of information technology, is described more broadly by identifying specific branches of industry: information technologies (IT), e-commerce and services of digital technologies, software production and information processing (Brynjolfsson \& Kahin, 2000). When analysing this model, the importance of digital technologies and the Internet penetration level is emphasised not only in the manufacturing but also in the service sector (Johansson et al., 2006).

British economist M. Skilton introduces digital economy as a part of the new digital ecosystem. The digital ecosystem is an interaction of information technologies in the market and business that creates new consumers, determines greater business results and provides a new experience. In the context of this ecosystem, the digital economy is viewed as virtual resources and digital services, creating added value for both the country and individual company (Skilton, 2015).

The Organisation for Economic Co-operation and Development (OECD) states that technologies are the foundation for the rapid digital transformation of society, economy and government. Digital transformation creates changes in the traditional order: new communication channels and means are introduced as well as business innovations, the functioning of business and the governance of states, based on the opportunities provided by the new technologies (OECD, 2017).

The interest in the digital economy is driven by the research of scientists and international organisations, which reveals that information technology is becoming increasingly important in the economic development of all world countries, whilst their integration into all areas of activity is gaining momentum. The high rate of digitisation is determined by its positive impact on the society, business and government that operate through three main mechanisms: inclusive, efficient and innovative (Table 1).

Table 1. Positive effects of digitisation (Source: author's compilation from Digital Dividends, 2016)

\begin{tabular}{|l|c|c|c|}
\cline { 2 - 4 } \multicolumn{1}{c|}{} & Inclusion & Efficiency & Innovation \\
\hline Society & Job opportunities & Labour productivity & Consumer welfare \\
\hline Businesses & Trade & Capital utilisation & Competition \\
\hline Governments & Participation & Public sector capability & Voice \\
\hline
\end{tabular}

Therefore, positive effects of digitisation on the society are the creation of new jobs, greater flexibility of working conditions (remote job positions), work automatisation that increases labour productivity and a broader range of goods and services available to the consumers, allowing to meet their considerable needs. As for business, the digitisation has created new trading markets, makes capital management more effective and profitable as well as promotes competition. Moreover, digitisation allows to include a greater number of residents into public activities at the government level, increases the number of services available to the society and creates conditions for the efficient and transparent work of the state machinery.

Nevertheless, though digitisation has positive effects on economy and society, it can also have a negative effect. In the World Bank Report of 2016, Digital Dividends distinguish these possible negative effects:

- Concentration: business interests of many industry branches, lack of sensible regulation and limited competition of digital platforms.

- Inequality: rapid work automatisation can lead to the disappearance of jobs, increased structural unemployment and growing inequality in society.

- Control: the state and organisations can use digital technologies for the control of citizens and not the development of their opportunities and rights (Digital Dividends, 2016). 
These negative effects should be reduced by regulating the activities of business so that the companies could apply the potential provided by the Internet for the increase of competitiveness and innovations; for the development of people's digital literacy that would provide more opportunities to use the advantages of information technologies; and for accountable state institutions that by controlling the use of technologies would improve the welfare of people. Digital technologies can strengthen the impact of these means as well as encourage an accelerated pace of the development of the digital economy and society.

Thus, the digital economy provides opportunities for society, companies and the state to create additional added value, to seek for greater efficiency and to create a welfare state. For this reason, the creation of the digital economy should be one of the essential goals of society and the state. If all the advantages are properly used and risks are managed, any country can achieve good results.

\section{Methodology}

As a trend of the modern world economy and society, digitisation has a different impact on separate countries. In order to assess the degree of digitisation of any country, indicators that measure it are used. The Digital Economy and Society Index (DESI) is applied in this research. This index is an online tool to measure the progress of the EU member states towards a digital economy and society (Europe's digital progress report, 2017).

DESI is a composite index measuring progress in digital performance through five components:

- Connectivity dimension measures the deployment of broadband infrastructure and its quality. This dimension is calculated using the five sub-dimensions: fixed broadband, mobile broadband, fast broadband, ultrafast broadband and broadband price index.

- Human capital dimension measures the skills needed to take advantage of the possibilities offered by digital means; it is calculated by using two sub-dimensions: basic skills and usage, and advanced skills and development.

- Use of Internet services by citizens dimension accounts for a variety of online activities, such as the consumption of online content; it is calculated by using three sub-dimensions: content, communication and transactions.

- Integration of digital technology dimension measures the digitalisation of businesses and eCommerce. This dimension is calculated by using two sub-dimensions: business digitization and eCommerce.

- Digital public services dimension measures the digitalisation of public services. Modernisation and digitalisation of public services can lead to efficiency gains for the public administration, citizens and businesses. This dimension focuses on eGovernment and eHealth (DESI indicators, 2018).

Some dimensions are more relevant than others, and for such a reason, they have been given a higher weight in the computation of the final index score of each country. The overall DESI has been calculated as the weighted average of the five main DESI dimensions by this formula:

$$
\begin{gathered}
\text { DESI }=\text { Connectivity } * 25 \%+\text { Human Capital } * 25 \%+\text { Use of Internet } * 15 \%+\text { Integration of Digital } \\
\text { Technology } * 20 \%+\text { Digital Public Services } * 15 \%
\end{gathered}
$$

Connectivity and Human Capital are the key dimensions of the DESI, as they empower and maintain the whole structure of the digital society and economy, as well as its functioning - infrastructure. These dimensions have the greatest weights: $25 \%$ each. In the business sector, Integration of Digital Technology is significant for growth and expansion; this dimension has $20 \%$ of the total weight. A crucial weight over 
the Use of Internet Services and Digital Public Services is held by the quality of infrastructure, as their joint contribution depends on it. These dimensions each have 15\% of the total weight (DESI Methodological note, 2018).

The main DESI, its sub-dimensions and individual indicators allow to carry out these types of analysis:

- Performance assessment: assessment of the performance of member states;

- Zooming-in: the identification of areas that need to be improved;

- Follow-up: the observation of progress;

- Comparative analysis: categorisation of member states in order to carry out a complex analysis (DESI Methodological note, 2018).

The study uses the DESI of 2018, which is published on the website of the European Commission. In order to assess the progress of the Baltic States in the overall context of the EU, each country is compared to the average of the 28 countries of the EU.

\section{Results}

In the study, the progress analysis of the Baltic States is carried out based on the DESI. The selection of the three Baltic States is conditioned by the fact that, in the context of the European Union, the Baltic States are usually viewed as one region because of their geographical location and similar development level of the economy. Moreover, these countries are also analogous in their history, culture and religion (Hiden \& Salmon, 2000; Mole, 2012).

First of all, the ranking of each Baltic State amongst all European countries should be disclosed (Figure 1). The average for all EU member states is also included in the comparison in order to reveal the gap amongst each of the Baltic States and common tendencies.

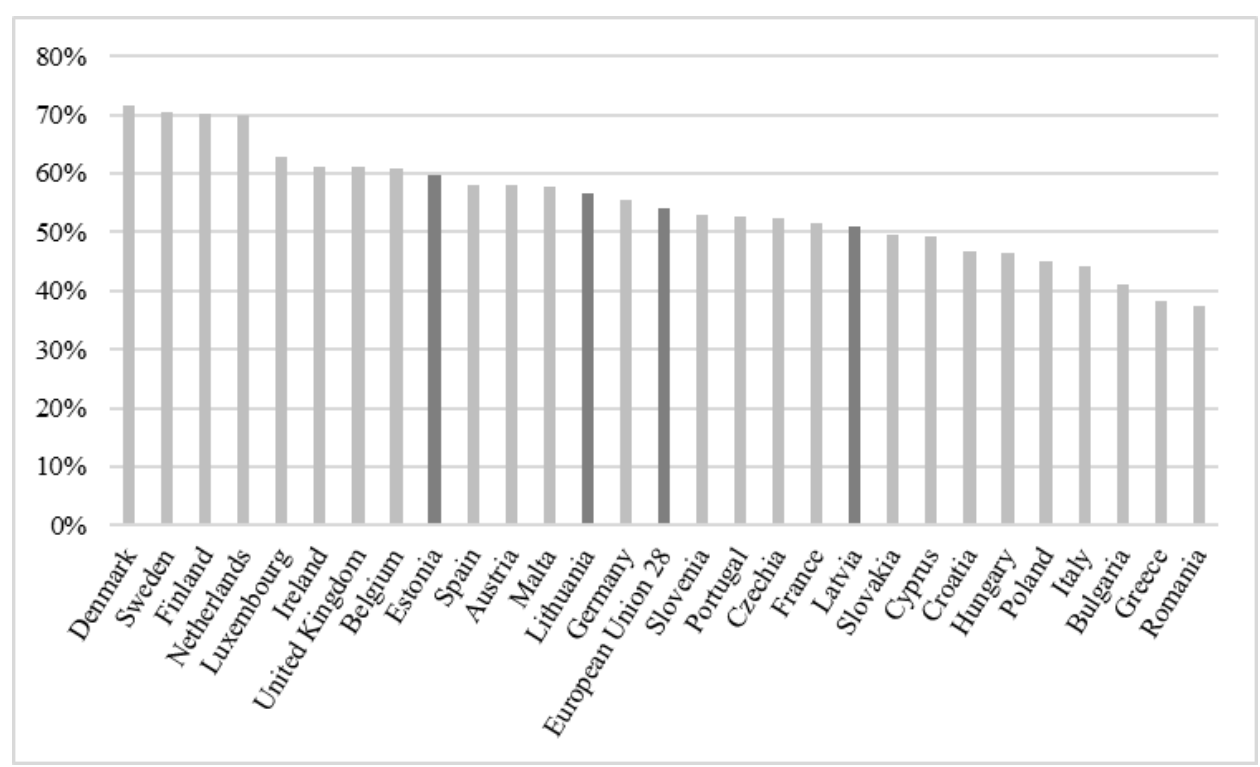

Fig. 1. DESI (Source: DESI, 2018)

According to the presented chart, Estonia has the highest ranking from all three of the Baltic States, based on the DESI. Amongst all the European countries, it is in the ninth place, and its index value is $60 \%$. The DESI value of Lithuania is $57 \%$, and this country ranks 13 th amongst the European countries, whereas Latvia has 54\% and takes up the 20th place. Estonia and Lithuania are above the EU average (54\%), whilst the value of the Latvian index is lower. Nevertheless, all three Baltic States need to exert themselves with 
the intention to overtake the leaders of the European Union: Denmark with $72 \%$ and Sweden, Finland and Netherlands all have approximately $70 \%$ value on the DESI.

The variation in the value of the DESI in the period of 2014-2018 shows the growth tendencies of the Baltic States and their gap when comparing them with each other and the average of the European Union (Figure 2).

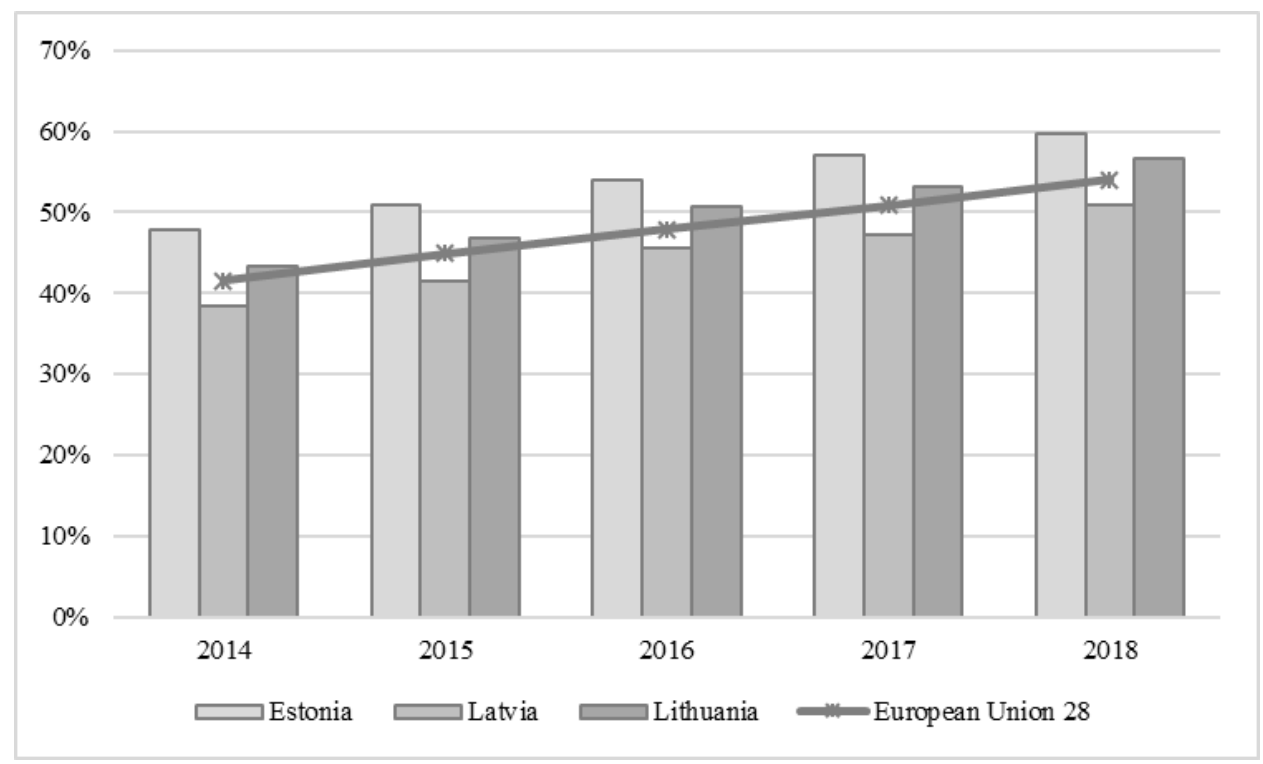

Fig. 2. Change in the DESI in 2014-2018 (Source: DESI, 2018)

During the analysed period, DESI values of all Baltic States increased. Throughout this period, Estonia is the leader according to the value of the index, whilst Lithuania takes the second place. Both countries are above the average of the EU. Meanwhile, Latvia has the lowest DESI value, in comparison with the other Baltic States and with the EU average. The increase in the DESI value was not equivalent during the 5-year period, which was analysed. The index value of Estonia rose steadily by $3 \%$ in each year; Lithuania's index value increased by $4 \%$, except for 2017 , when the growth slowed down to $2 \%$. Latvia has similar growth trends as Lithuania; nevertheless, its growth in 2017 was even slower and reached only $1 \%$. The EU average grew steadily by $3 \%$ each year.

The overall value of the DESI is constituted of the weighted average of five dimensions. When comparing the values of the DESI dimensions amongst the Baltic States and the EU average, advanced and improving areas can be observed (Figure 3). 


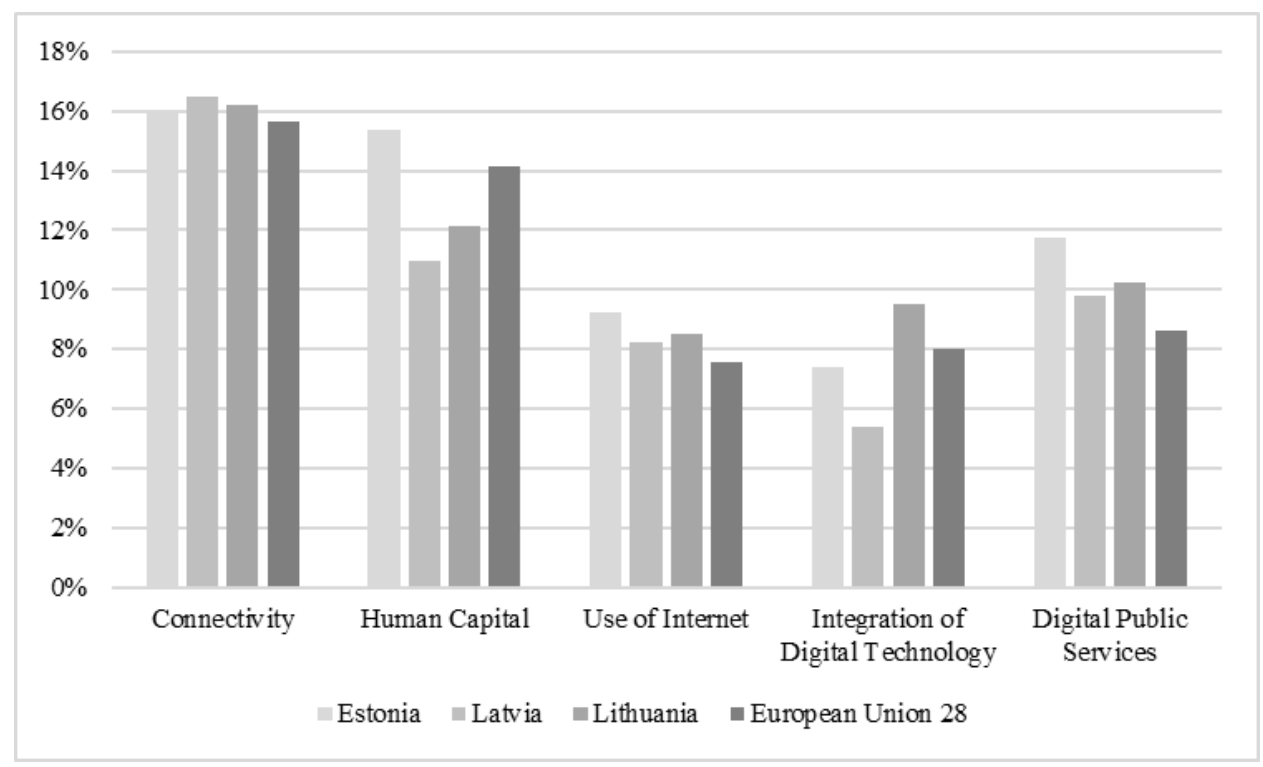

Fig. 3. DESI by dimensions (Source: DESI, 2018)

When comparing the DESI based on the values of different dimensions, it has been determined that according to the Connectivity dimension, all the Baltic States are at an almost identical level and exceeds the EU average. Latvia has the highest value of this dimension (16.48\%), whereas Lithuania's and Estonia's values are $16.22 \%$ and $16.03 \%$, respectively. Meanwhile, the EU average is $15.64 \%$.

Whilst assessing the values of other dimensions, the differences are more pronounced. According to the value of the Human Capital dimension, Estonia is the leader with $15.34 \%$ and is the only Baltic state that exceeds the average of the European Union, which is $14.12 \%$. The value of the Human Capital dimension for Lithuania is $12.13 \%$, whereas that for Latvia is $10.96 \%$. According to the dimension Use of Internet, Estonia also takes up the first place with 9.24\%, whilst Lithuania is in the second place with $8.53 \%$; Latvia is quite close to Lithuania with $8.22 \%$. According to the Use of Internet dimension, all three Baltic States surpass the EU average, which is $7.57 \%$. In terms of the Integration of Digital Technology dimension, the highest value belongs to Lithuania, which is $9.49 \%$. This value is higher than the EU average: $8.02 \%$. Values of the other two Baltic States Estonia and Latvia are 7.41\% and 5.41\%, respectively. According to the Digital Public Services dimension, the highest rank belongs to Estonia, which is $11.72 \%$; Lithuania is not that far behind with $10.23 \%$, whereas the value of this dimension for Latvia is $9.78 \%$. All three Baltic States are above the EU average (8.62\%), based on the Digital Public Services dimension.

Summarising the comparison of the Baltic States based on the values of the DESI dimensions, it can be stated that Estonia has the highest values in three of the five dimensions: Human Capital, Use of Internet and Digital Public Services; nevertheless, it should promote progress in the Integration of Digital Technology dimension. Latvia takes the first position in the dimension of Connectivity; however, it should encourage progress in all other dimensions. Lithuania has overtaken other two Baltic States in the Integration of Digital Technology dimension, whereas in other dimensions, it occupies the middle position.

According to the comparison of Baltic States and the average of the European Union, based on the values of the DESI dimensions, it can be stated that the dimensions with higher values reflect the advanced areas of the countries in the overall context of the EU, whereas smaller values indicate the areas that need to be improved (Table 2). 
Table 2. Comparison of the values of the DESI dimensions of the Baltic States with the average of the European Union (Source: author's compilation by DESI, 2018)

\begin{tabular}{|c|c|c|}
\hline Country & Above the average of the European Union & Below the average of the European Union \\
\hline Estonia & $\begin{array}{c}\text { Connectivity; Human Capital; Use of Internet; } \\
\text { Digital Public Services }\end{array}$ & Integration of Digital Technology \\
\hline Latvia & $\begin{array}{c}\text { Connectivity; Use of Internet; Digital Public } \\
\text { Services }\end{array}$ & $\begin{array}{c}\text { Human Capital; } \\
\text { Integration of Digital Technology }\end{array}$ \\
\hline Lithuania & $\begin{array}{l}\text { Connectivity; Use of Internet; Integration of } \\
\text { Digital Technology; Digital Public Services }\end{array}$ & Human Capital \\
\hline
\end{tabular}

In order to analyse the problems of the areas that need to be improved in each of the Baltic States, the subdimensions of each of the dimension should be analysed.

It is essential for Estonia and Latvia to encourage the progress in the Integration of Digital Technology dimension. Sub-dimensions of this dimension are Business digitisation (60\%) and eCommerce (40\%); the weight of these sub-dimensions in the overall dimension is $60 \%$ and $40 \%$, respectively. The Business digitisation sub-dimension shows the uptake level of digital technologies in the country's companies. The values of the sub-dimension of the Integration of Digital Technology component reveal the specific field for improvement in Estonia and Latvia (Figure 4).

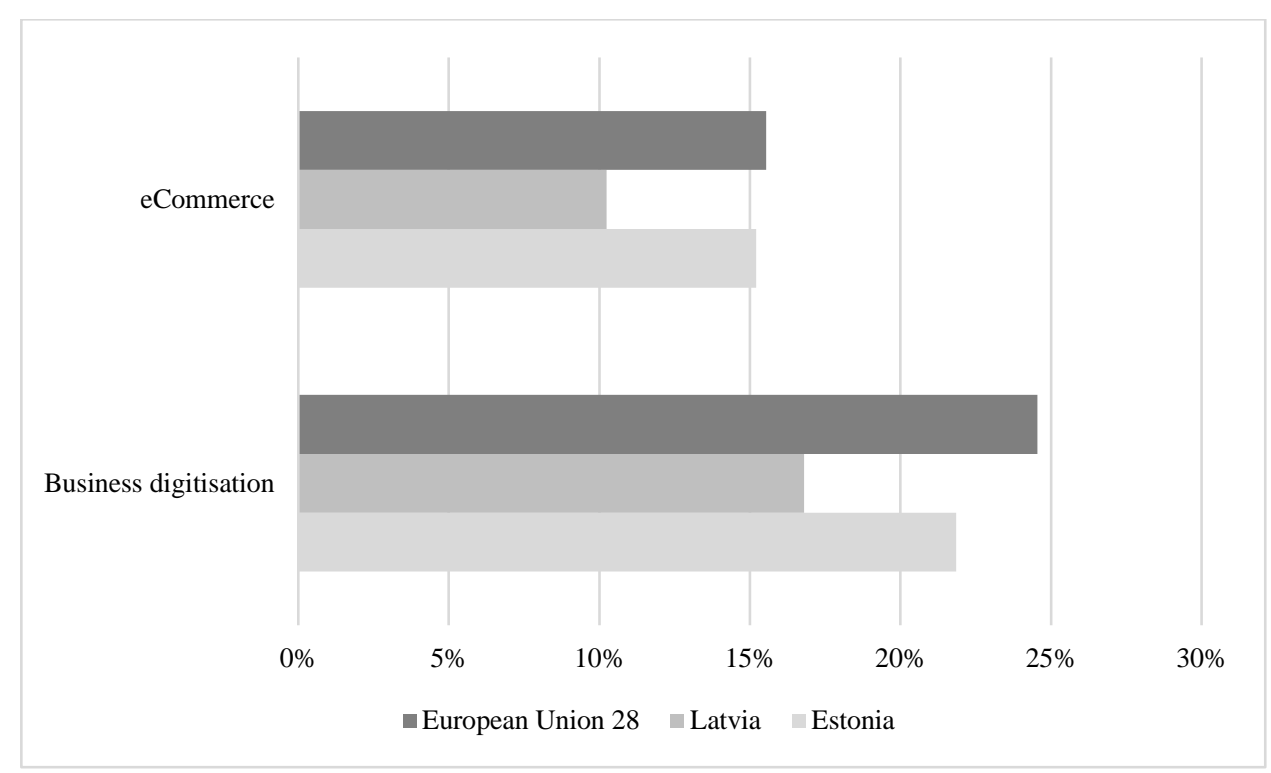

Fig. 4. Comparison of Integration of Digital Technology sub-dimension of Estonia and Latvia with the EU average (Source: DESI, 2018)

Estonia's eCommerce sub-dimension is quite close to the EU average; thus, the focus should be on the strengthening of the elements of Business digitisation sub-dimension. Latvia should concentrate on the development of both sub-dimensions. The strengthening of Business digitisation should focus on five technologies: the electronic sharing of information inside the company, the use of Radio-frequency Identification technologies, the communication through social networks as well as the use of e-invoices and Cloud services (DESI Methodological note, 2018). eCommerce provides opportunities to become a part of 
a much greater market and produces a higher growth potential; therefore, it is beneficial to promote eCommerce of country's companies in the internal market and the markets of other EU countries.

Latvia, as well as Lithuania, should focus on the strengthening of the elements of the Human Capital dimension. The Human Capital dimension is divided into two sub-dimensions: the Basic Skills and Usage sub-dimension (50\%), which indicates general population's level of digital skills, and the Advanced Skills and Development (50\%), which is concerned with the personnel and its potential to preserve and increase the digital economy. The values of Human Capital sub-dimension for Lithuania and Latvia reveal the weakest areas in the EU context (Figure 5).

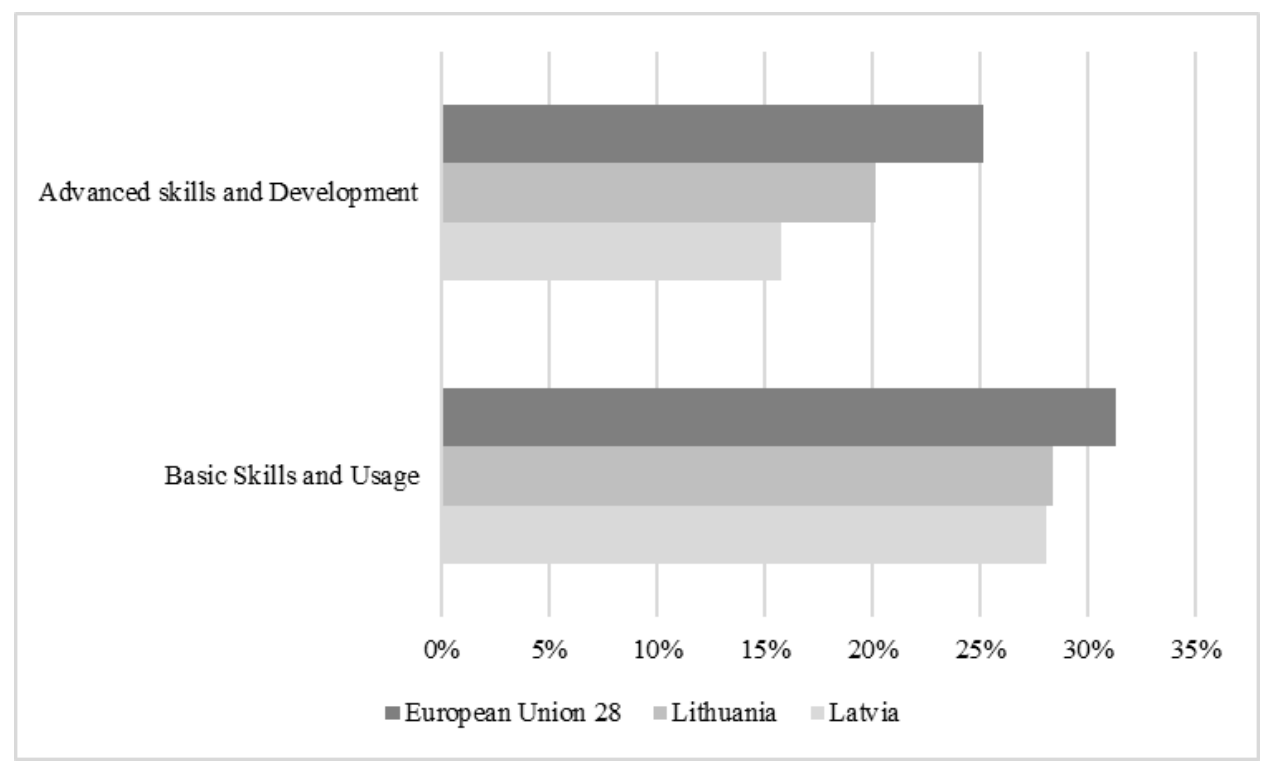

Fig. 5. Comparison of Human Capital sub-dimension of Latvia and Lithuania with the EU average (Source: DESI, 2018)

According to the values of both sub-dimensions, Latvia and Lithuania lag behind the EU average. Thus, both countries should increase the number of regular Internet users as well as residents' computer literacy (Basic Skills and Usage sub-dimension). Digital skills could also help to solve more general problems, as these skills are significant to the digital economy labour market. The strengthening of the digital skills of all residents has a positive impact on the key competencies required in the labour market. When it comes to the Advanced Skills and Development sub-dimension, both countries are facing a serious challenge: to manage the transition from a low-cost, low-tech economy to a proficient economy that is open to skills and innovations.

\section{Conclusions}

The digital economy is a rapidly developing model of the economy that is based on the satisfaction of various needs of society and organisations as well as the creation of added value by using digital technologies.

The advantages of this economic model are revealed through three mechanisms: inclusive, efficient and innovative. The inclusive mechanism is displayed by new jobs, a wider commerce market and the inclusion of society into the governance of the state. The effective mechanism is shown through the increase in labour productivity, better capital management and the increased public sector capacity, whereas the innovative mechanism increases the satisfaction of the customers, competition amongst organisations and improves the 
state's communication with society. However, it is necessary to assess and manage the risks of this economic model, that is, the concentration that requires regulation, the inequality that needs to increase the level of society's digital literacy and control that is diminished by accountability.

By assessing the Baltic States according to their digital progress in the context of the whole European Union, the DESI published by the European Commission is used. On the basis of the DESI, the highest rating from all three Baltic States is acquired by Estonia; it is the 9th amongst all the countries of the European Union. According to the DESI, Lithuania takes the 13th place, whereas Latvia is in the 20th position. The DESI of all three Baltic Countries increased during the period 2014-2018. By comparing it with the average of the European Union, the DESI of Estonia and Lithuania is higher, whilst that of Latvia is lower than the average of the European Union.

By analysing the Baltic States based on the DESI dimensions, it can be concluded that all three countries are advanced in the dimensions of Connectivity, Use of Internet and Digital Public Services. However, in other dimensions, only a little progress is visible in comparison with other EU countries. Estonia and Latvia should promote progress in the dimension of the Integration of Digital Technology by encouraging the level of digital technology inclusion in businesses and by expanding the usage of the eCommerce channel in the country. Latvia, as well as Lithuania, should focus on the strengthening of the Human Capital dimension by increasing the number of regular Internet users and raising the level of computer literacy amongst their citizens. It can be stated that all the Baltic States do not fully use their digital technologies potential for the development of the economy.

\section{References}

Brynjolfsson E., Kahin B. (2000). Understanding the Digital Economy: Data, Tools, and Research. [Accessed 16.03.2019]. Available from Internet: https://books.google.lt/books?id=dpf2hL6EGcC\&pg=PA13\&hl=lt\&source=gbs_toc_r\&cad=4\#v=onepage \&q \&f=false

Cardoso, G., Castells, M. (2006). The Network Society: From Knowledge to Policy. [Accessed 16.03.2019]. Available from Internet: https://www.researchgate.net/publication/301788885_The_Network_Society_From_Knowledge_to_

Carlsson B. (2004). The Digital Economy: what is new and what is not? [Accessed 16.03.2019]. Available from Internet: https://www.oecd-ilibrary.org/docserver/9789264218789-7-

en.pdf?expires $=1554145613 \& \mathrm{id}=\mathrm{id} \& \mathrm{accname}=$ guest $\&$ checksum $=06 \mathrm{~B} 5 \mathrm{BC} 743 \mathrm{~A} 75503 \mathrm{E} 665858 \mathrm{E} 683151822$

DESI (2018). Digital Economy and Society Index. [Accessed 16.03.2019]. Available from Internet: https://digitalagenda-data.eu/datasets/desi/visualizations

DESI (2018). Indicator list. [Accessed 16.03.2019]. Available from Internet: https://digital-agendadata.eu/datasets/desi/indicators

DESI (2018). Methodological note. [Accessed 16.03.2019]. Available from Internet: http://ec.europa.eu/information_society/newsroom/image/document/2018-20/desi-2018-methodology_E886EDCAB32A-AEFB-07F5911DE975477B_52297.pdf

Digital Dividends. (2016). World Development Report. [Accessed 16.03.2019]. Available from Internet: http://www.worldbank.org/en/publication/wdr2016

Europe's digital progress report. (2017). Report. [Accessed 16.03.2019]. Available from Internet: https://ec.europa.eu/digital-single-market/en/news/europes-digital-progress-report-2017

Johansson B., Karlsson Ch., Stough R. (2006). The Emerging Digital Economy: Entrepreneurship, Clusters, and Policy. [Accessed 16.03.2019]. Available from https://books.google.lt/books?id=rc1EAAAAQBAJ\&printsec $=$ frontcover\&hl=lt $\mathrm{v}=$ onepage\&q $\& \mathrm{f}=$ false

Hiden, J., \& Salmon, P. (2014). The Baltic nations and Europe: Estonia, Latvia and Lithuania in the twentieth century. [Accessed 13.05.2019]. Available from Internet: https://books.google.lt/books?hl=lt\&lr=\&id=itsAgAAQBAJ\&oi=fnd\&pg=PP1\&ots=qM5RC2UVhx\&sig=E7Iglu7jNsg9_hOKq_X90qFpd9M\&redir_esc=y\#v=one page\&q\&f=false. 
Khalin V.G., Chernova G.V. (2018). Digitalization and Its Impact on the Russian Economy and Society: Advantages, Challenges, Threats and Risks. [Accessed 16.03.2019]. Available from Internet: https://doi.org/10.22394/1726-11392018-10-46-63

Mole R. (2012). The Baltic States from the Soviet Union to the European Union. [Accessed 13.05.2019]. Available from Internet: https://www.taylorfrancis.com/books/9780203121498

Morkūnienè J. (2002). Informaciniu technologiju visuomené: humanitarinès interpretacijos. Vilnius: Lietuvos teisès universiteto Leidybos centras. [Accessed 16.03.2019]. Available from Internet: https://repository.mruni.eu/ds2/stream/?\#/documents/26ef2fe7-4771-46af-9817-3d7e921fac74/page/1

Negroponte N. (1995). Being Digital. [Accessed 16.03.2019]. Available from Internet: https://books.google.lt/books?id=TDXqBQAAQBAJ\&printsec=frontcover\&dq=Being+Digital\&hl=lt\&sa=X\&ved=0 ahUKEwi4-tvjxK_hAhWypYsKHVykAQ8Q6AEIKDAA\#v=onepage\&q=Being\%20Digital\&f=false.

OECD. (2017). Digital Economy Outlook. [Accessed 16.03.2019]. Available from Internet: https://espas.secure.europarl.europa.eu/orbis/sites/default/files/generated/document/en/9317011e.pdf

Parente, R. C., Geleilate, J. G., \& Rong, K. (2017). The Sharing Economy Globalization Phenomenon: A Research Agenda. Journal of International Management. [Accessed 16.03.2019]. Available from Internet: https://www.sciencedirect.com/science/article/abs/pii/S107542531730162X)

Skilton M. (2015). Building the Digital Enterprise: A Guide to Constructing Monetization Models Using Digital Technologies. Berlin: Springer. 230 p. [Accessed 16.03.2019]. Available from Internet: https://books.google.lt/books?id=v9RgCgAAQBAJ\&printsec=frontcover\&dq=Building + the + Digital + Enterprise: $+\mathrm{A}$ +Guide+to+Constructing+Monetization+Models+Using+Digital+Technologies\&hl=lt\&sa=X\&ved=0ahUKEwiIs_f2 86LhAhXqs4sKHWDtDigQ6AEIKzAA\#v=onepage\&q=Building\%20the\%20Digital\%20Enterprise\%3A\%20A\%20 Guide\%20to\%20Constructing\%20Monetization\%20Models\%20Using\%20Digital\%20Technologies\&f=false

Tapscott D. (1996). The Digital Economy: Promise and Peril in the Age of Networked Intelligence. [Accessed 16.03.2019]. Available from Internet: http://dontapscott.com/books/the-digital-economy/.

Иванов В.В., Малинецкий Г.Г. (2017). Цифровая экономика: мифы, реальность, перспектива. [Accessed 16.03.2019]. Available from Internet: http://www.ras.ru/FStorage/Download.aspx?id=33ce1a09-9923-4a20-a21cba39489d1c14 